University of Nebraska - Lincoln

DigitalCommons@University of Nebraska - Lincoln

Faculty Publications: Department of Entomology

Entomology, Department of

October 1997

\title{
Differential Toxicity of Atrazine to Selected Freshwater Algae
}

\author{
J.-X. Tang \\ University of Nebraska-Lincoln \\ Kyle D. Hoagland \\ University of Nebraska-Lincoln, khoagland1@unl.edu \\ Blair D. Siegfried \\ University of Nebraska-Lincoln, bsiegfried1@ufl.edu
}

Follow this and additional works at: https://digitalcommons.unl.edu/entomologyfacpub

Part of the Entomology Commons

Tang, J.-X.; Hoagland, Kyle D.; and Siegfried, Blair D., "Differential Toxicity of Atrazine to Selected Freshwater Algae" (1997). Faculty Publications: Department of Entomology. 65.

https://digitalcommons.unl.edu/entomologyfacpub/65

This Article is brought to you for free and open access by the Entomology, Department of at DigitalCommons@University of Nebraska - Lincoln. It has been accepted for inclusion in Faculty Publications: Department of Entomology by an authorized administrator of DigitalCommons@University of Nebraska - Lincoln. 


\title{
Differential Toxicity of Atrazine to Selected Freshwater Algae
}

\author{
J.-X. Tang, ${ }^{1}$ K. D. Hoagland, ${ }^{2}$ and B. D. Siegfried ${ }^{1}$ \\ ${ }^{1}$ Department of Entomology, University of Nebraska, 202 Plant Industry Building, Lincoln, \\ Nebraska 68583, USA \\ ${ }^{2}$ Department of Forestry, Fisheries and Wildlife, University of Nebraska, 101 Plant Industry \\ Building, Lincoln, Nebraska 68583 \\ Corresponding author - B. D. Siegfried
}

The documented presence of atrazine in surface waters has prompted a large number of studies on its potential adverse effects on nontarget organisms such as freshwater algae, which are the most important primary producers in aquatic habitats and are potential indicators of water quality (Blaise 1993). Recently, a comprehensive database of the ecological effects of atrazine, including 85 freshwater organisms, was compiled (Solomon et al. 1996). Based on this compilation of acute ( $\leq 4$ day) or chronic ( $>9$ day) toxicity values, algae are the most susceptible aquatic organisms to atrazine, although it is apparent that different species and divisions of freshwater algae exhibit varying levels of response to atrazine exposure.

Numerous studies have indicated that atrazine inhibits growth and photosynthesis of freshwater algae and algal responses to atrazine vary widely depending upon concentrations used, duration of exposure, and algal species tested. However, there are few studies that directly compare the effects of atrazine between different divisions of freshwater algae, and most studies have focused on short-term (up to $96 \mathrm{hrs}$ and 7 days) growth inhibition with a limited number algal species (Larsen et al. 1986, Walsh et al. 1987, Hersh and Crumpton 1989, Abou-Waly et al. 1991, Kasai et al. 1993, Kirby and Sheahan 1994). Very few studies have focused on long-term (over 14 days) toxicity tests (Kirkwood and Fletcher 1970, Johnson 1986, Megharaj et al. 1987, Okay and Morkoc 1994). Atrazine is relatively persistent in water, and its concentrations would not be expected to vary greatly over time, especially in short-term bioassays (Solomon et al. 1996). More recent testing procedures have recognized that, because of the wide range of sensitivity observed, a battery of species is recommended to improve algal toxicity detection and predictability in chemical evaluation (Boutin et al. 1993). Therefore, in the present study eight freshwater algal species from two divisions were chosen and the effects of atrazine on these algae were assessed over 28 days. The objectives of this study were to examine the effects of atrazine on growth of four green algae and four diatoms and to quantify the differences to atrazine exposure between the tolerance levels of these two algal divisions.

\section{MATERIALS AND METHODS}

Four species of green algae and four species of diatoms were selected based on their availability in culture collections and their ability to grow under similar conditions (temperature, lighting, and nutrition). The test species represented a wide range in taxonomy, morphology and physiology. Green algae (Chlamydomonas sp., Chlorella sp., Pediastrum sp., 
and Scenedesmus quadricauda) were obtained from Carolina Biological Supply Company (Burlington, NC). Diatoms (Cyclotella gamma, C. meneghiniana, Synedra acus, and S. radians) were obtained from the Loras College culture collection (Dubuque, IA). All algae were grown under axenic conditions. Green algae were grown in WC freshwater medium (Guillard 1975), and diatoms were grown in Chu \#10 medium (Nichols 1973). Cultures were incubated at $20^{\circ} \mathrm{C}$ with an alternate $12 / 12$ light:dark cycle using cool-white fluorescent lamps at ca. $100 \mu \mathrm{M} \mathrm{m}^{-2} \mathrm{~s}^{-1}$. Cultures were shaken at $150 \mathrm{rpm}$ for $7-10$ days to obtain algal cultures in exponential growth phase before initiating bioassays.

Technical atrazine (2-chloro-4-ethylamino-6-isopropylamino-s-triazine) (99.8\% pure) was obtained from Supelco, Inc. (Belletonete, PA) and used in all bioassays. Screw-capped glass tubes $(150 \mathrm{~mm} \times 22 \mathrm{~mm}$ diameter), each containing $14.5 \mathrm{~mL}$ autoclaved medium, were inoculated with $0.5 \mathrm{~mL}$ aliquots of fresh cell suspension (7-10 days old). Fifteen $\mu \mathrm{L}$ of atrazine solution (dissolved in acetone) was added to each tube providing nominal concentrations of $1,10,100,250,500$, and $1000 \mu \mathrm{g}$ atrazine/L medium. The final concentration of acetone was $0.1 \%$. Preliminary analysis indicated that this concentration had no effect on algal growth. Three replicate tubes were used at each atrazine concentration. Untreated controls received only $0.1 \%$ acetone. The final volume in each experimental system was $15 \mathrm{~mL}$ (Kent and Currie 1995). All tested species exhibited sustained growth based on both cell density and chlorophyll $a$ for up to 28 days (data not shown). Samples were withdrawn after 7, 14, 21 and 28 days. For each sample, growth was determined using two methods: (1) spectrophotometric determination of optical density, and (2) fluorometric measurement of chlorophyll $a$ content.

For optical density determination, three test tubes were randomly withdrawn and thoroughly vortexed for each concentration and each time point. Optical density was measured at $680 \mathrm{~nm}\left(\mathrm{OD}_{680}\right)$ in a Beckman DU-65 Spectrophotometer (Beckman Instruments, Palo Alto, CA). Kasai et al. (1993) reported that cell numbers and $\mathrm{OD}_{680}$ are highly correlated. A strong correlation between optical densities and cell densities of the algae tested was confirmed in this experiment, with $\mathrm{r}^{2}$ values $>0.97$ for all algal species tested. Optical density was then used as a surrogate for growth (cell density) for each freshwater alga. The method of Welschmeyer (1994) without acidification was used for fluorometric measurement of chlorophyll $a$ content. After optical density measurement, a known volume of suspended algal sample was passed through a Whatman GF/A filter. The filter was then placed in a sealed screw-capped glass tube containing $10 \mathrm{~mL} 90 \%$ ethanol to prevent evaporation. The test tubes were placed in a $78^{\circ} \mathrm{C}$ water bath for 5 min (without light) and then cooled in the dark at room temperature. The extract was decanted into a clean cuvette, and fluorescence was read with a Model 10-AU Fluorometer (Turner Designs, Sunnyvale, CA) calibrated with standard solutions of chlorophyll $a$ obtained from Sigma Chemical Company (St. Louis, MO). The chlorophyll $a$ content in each sample was expressed as $\mu \mathrm{g} / \mathrm{L}$.

The percent inhibition (\%I) of algal growth for each atrazine concentration was calculated by comparing mean $\mathrm{OD}_{680}$ values and chlorophyll $a$ content to control samples (U.S. EPA 1989). Atrazine concentrations that inhibit algal growth (cell density and chlorophyll $a$ content) by $50 \%$ relative to controls $\left(\mathrm{EC}_{50} \mathrm{~s}\right)$ were calculated using the Probit Procedure (SAS Institute 1994) with log transformed values of test atrazine concentrations. The statistically significant effects of atrazine on growth of different algae species was determined using analysis of variance (ANOVA), in conjunction with Duncan's multiple range test (SAS Institute 1994) with 95\% confidence intervals $(p<0.05)$. 


\section{RESULTS AND DISCUSSION}

The inhibitory effects of atrazine on algal growth as measured by optical density and chlorophyll $a$ fluorescence of green algae and diatoms are presented in Figures 1 and 2, respectively. Based on comparisons with controls, various growth-response patterns were observed following atrazine treatment. At $10 \mu \mathrm{g} / \mathrm{L}$, atrazine was slightly inhibitory based on both cell density and chlorophyll $a$ in a number of species. However, this same concentration stimulated cell density and chlorophyll $a$ for others. For example, both cell density and chlorophyll $a$ content were consistently higher for Chlamydomonas sp. and Synedra acus at $1 \mu \mathrm{g} / \mathrm{L}$ (data not shown) and $10 \mu \mathrm{g} / \mathrm{L}$ at all time points. The growth of all species was inhibited almost completely by atrazine at $1,000 \mu \mathrm{g} / \mathrm{L}$ after 14 days, but did not exceed $80 \%$ for the 7 -day readings. Growth inhibition became most evident at $100 \mu \mathrm{g} / \mathrm{L}$ for most of the green algae, although a sharp increase in growth inhibition did not occur until $250 \mu \mathrm{g} / \mathrm{L}$ for most diatoms. Optical density and chlorophyll $a$ measurements produced similar inhibition curves indicating that cell density and chlorphyll $a$ content responded similarly to atrazine exposure.

50 values (effective concentrations that caused 50\% inhibition compared with the controls) were calculated for each species at 7, 14, 21 and 28 days after treatment for both opitical density (Table 1) and chlorophyll $a$ (Table 2) measurements. The $\mathrm{EC}_{50}$ values varied significantly among the different species and divisions of the algae tested, and the $\mathrm{EC}_{50}$ values for diatoms were generally higher than those of green algae. At 7- to 14-day exposures, the green alga Chlamydomonas sp. was the most susceptible species among all the species tested, and the diatom C. meneghiniana was the most tolerant. The $\mathrm{EC}_{50}$ values for all species except Chlamydomonas sp. were generally higher for the 7-day exposure than for other time points, and differences in $\mathrm{EC}_{50}$ values among species were more apparent at 7 days than at the other time points.

In the evaluation of ecotoxicological risk of herbicides, values of sensitive species have been an important consideration (Huber 1993). $\mathrm{EC}_{50}$ values are useful to more exactly determine the range of pesticide concentrations that cause growth inhibition in an algal population (Anton et al. 1993). E C50 values from this study are similar to those reported for other algal species (Solomon et al. 1996, Huber 1993). Atrazine was highly toxic to all the freshwater algal species tested. Growth inhibition was detected in some species at concentrations as low as $10 \mu \mathrm{g} / \mathrm{L}$ and complete inhibition was observed at $1,000 \mu \mathrm{g} / \mathrm{L}$. Although atrazine was clearly toxic to all species tested, there was a broad range of sensitivity among species, and in general, green algae were more susceptible to atrazine than diatoms. Previous studies at the community level have suggested similar differences in atrazine toxicity to freshwater algae. Herman et al. (1986) observed a shift from a chlorophyte- to a diatom-dominated community after atrazine treatment to an in situ, enclosed periphyton community. Shehata et. al. (1993) also reported that green algae and bluegreen algae declined while diatoms increased in the presence of $0.01 \mathrm{mg} / \mathrm{L}$ of the triazine herbicide, gardoprim. This differential sensitivity to toxins among freshwater algae could have serious impacts on community structure and seasonal successional patterns (Hersh and Crumpton 1987), and any inhibitory effects of atrazine to freshwater algae should be considered environmentally significant.

At low concentrations, atrazine stimulated both growth and chlorophyll $a$ content of the green alga Chlamydomonas sp. and diatom Synedra acus. These results are consistent with other reports indicating stimulatory effects of atrazine at low concentrations. ElDib et al. (1989) reported that gardoprim, which is structurally very similar to atrazine, 

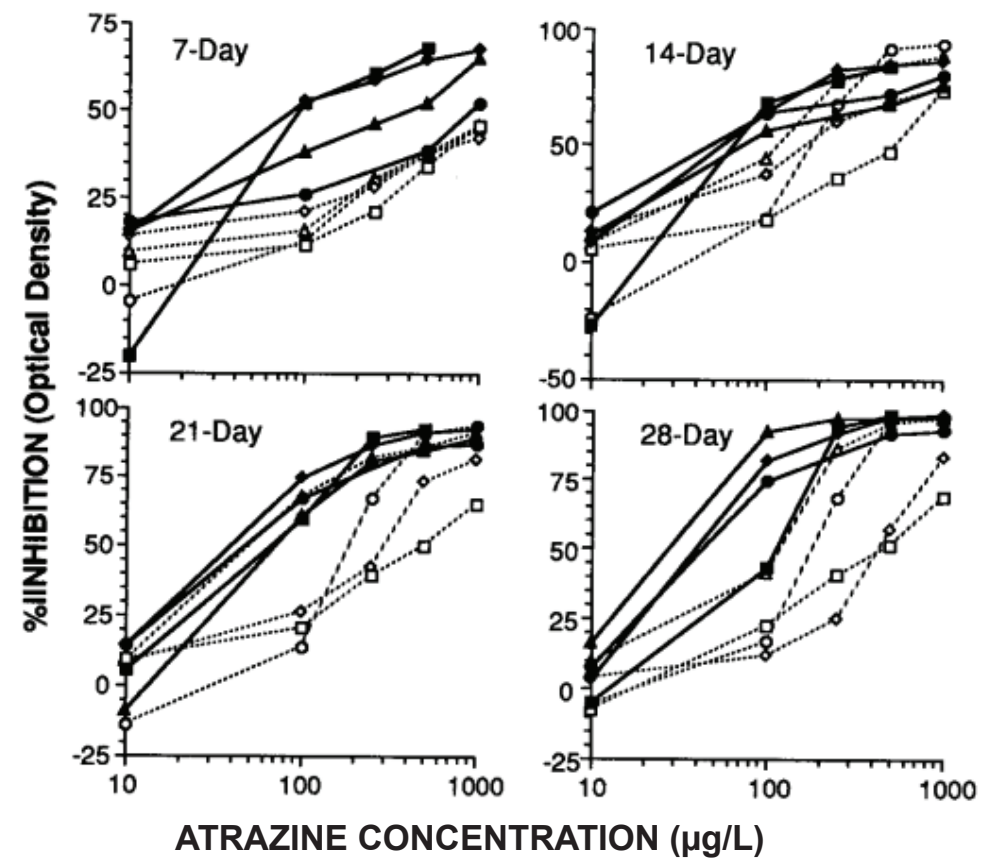

Figure 1. Atrazine inhibition of optical density in green algae (- - Chlamydomonas sp., - - Chlorella sp., - - - Pediastrum sp., and - - - Scenedesmus quadricauda) and diatoms (-- --- Cyclotella gamma, -- -- C. meneghiniana, -- $\Delta--$ Synedra acus, and --o-- S. radians). Each point represents the mean of three determiniations.

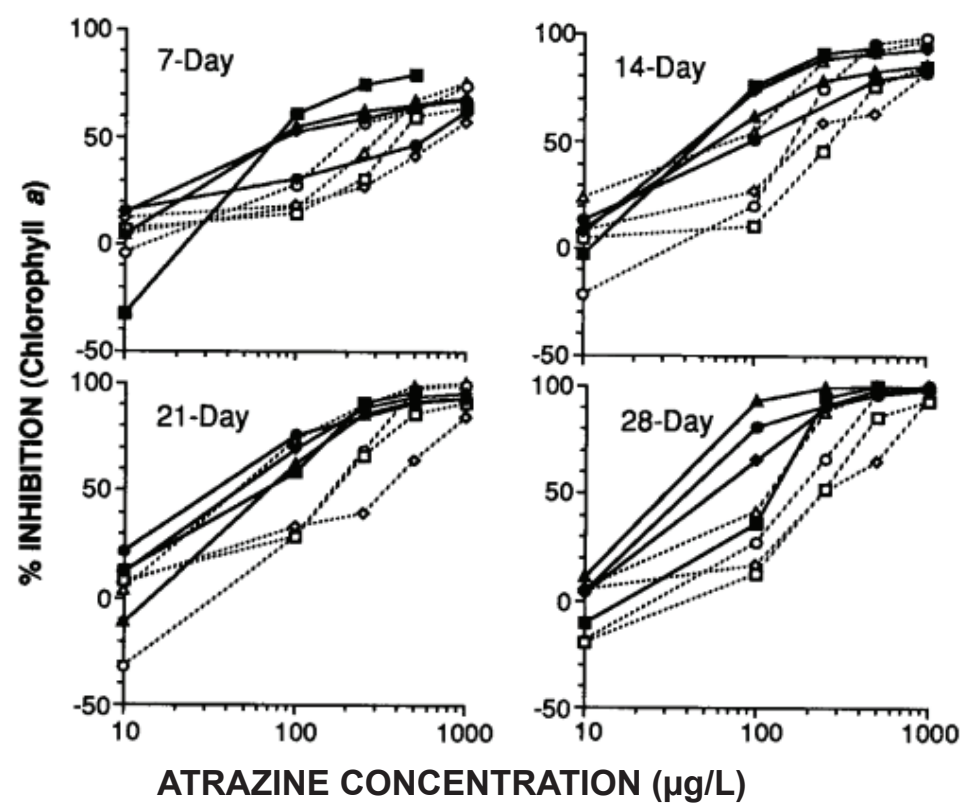

Figure 2. Atrazine inhibition of chlorophyll a in green algae (- - Chlamydomonas sp., - - Chlorella sp., - - - Pediastrum sp., and - - - Scenedesmus quadricauda) and diatoms (--口-- Cyclotella gamma, -- - -- C. meneghiniana, -- $\Delta--$ Synedra acus, and --o-- S. radians). Each point represents the mean of three determiniations. 
Table 1. $\mathrm{EC}_{50}$ values for atrazine toxicity to selected freshwater algae based on optical density.

\begin{tabular}{|c|c|c|c|c|}
\hline \multirow[b]{2}{*}{ Algae } & \multicolumn{4}{|c|}{ Atrazine $\mathrm{EC}_{s_{0}}(\mu \mathrm{g} / \mathrm{L})^{1}$} \\
\hline & 7-Day & 14-Day & 21-Day & 28-Day \\
\hline \multicolumn{5}{|l|}{ DIATOMS } \\
\hline Cyclotella gamma & $1552.4 \pm 26.2 \mathrm{a}$ & $447.6 \pm 16.7$ a & $493.3 \pm 24.6 \mathrm{a}$ & $429.7 \pm 21.7$ a \\
\hline $\begin{array}{l}\text { Cyclotella } \\
\text { meneghiniana }\end{array}$ & $3213.7 \pm 95.6 \mathrm{~b}$ & $180.4 \pm 3.3 b$ & $244.9 \pm 16.7 \mathrm{~b}$ & $417.3 \pm 11.3 \mathrm{a}$ \\
\hline Synedra acus & $1173.2 \pm 23.9 \mathrm{c}$ & $180.1 \pm 6.7 b$ & $203.4 \pm 5.8 \mathrm{c}$ & $204.3 \pm 5.6 \mathrm{~b}$ \\
\hline Synedra radians & $1488.6 \pm 88.6 \mathrm{c}$ & $113.8 \pm 4.4 c$ & $68.7 \pm 2.2 \mathrm{~d}$ & $88.9 \pm 4.7 \mathrm{~d}$ \\
\hline \multicolumn{5}{|l|}{ GREEN ALGAE } \\
\hline Chlamydomonas sp. & $80.6 \pm 3.6 \mathrm{f}$ & $26.2 \pm 2.6 \mathrm{e}$ & $73.4 \pm 3.8 \mathrm{~d}$ & $110.6 \pm 8.5 \mathrm{c}$ \\
\hline Chlorella sp. & $155.2 \pm 4.5 \mathrm{f}$ & $56.2 \pm 2.8 \mathrm{e}$ & $46.8 \pm 2.6 \mathrm{e}$ & $53.1 \pm 2.3 \mathrm{e}$ \\
\hline Pediastrum sp. & $1282.2 \pm 38.9 \mathrm{c}$ & $66.6 \pm 4.6 b$ & $51.7 \pm 2.2 \mathrm{de}$ & $51.9 \pm 2.3 \mathrm{e}$ \\
\hline $\begin{array}{l}\text { Scenedesmus } \\
\text { quadricauda }\end{array}$ & $333.8 \pm 18.4 \mathrm{e}$ & $124.2 \pm 7.5 \mathrm{~b}$ & $50.7 \pm 5.3 \mathrm{de}$ & $27.6 \pm 2.1 \mathrm{f}$ \\
\hline
\end{tabular}

${ }^{1}$ Mean \pm SEM of three separate determinations. Differences among treatment means determined by analysis of variance $(P<0.05)$. Means followed by the same letter within columns are not significantly different $(P>0.05$; Duncan's multiple range test $)$.

Table 2. $\mathrm{EC}_{50}$ values for atrazine toxicity to selected freshwater algae based on Chlorphyll $a$ content.

$$
\text { Atrazine } \mathrm{EC}_{30}(\mu \mathrm{g} / \mathrm{L})^{1}
$$

\begin{tabular}{lllll}
\cline { 2 - 3 } Algae & $14-\mathrm{D}$ ay & $21-\mathrm{D}$ ay & $28-\mathrm{D}$ a y \\
\hline
\end{tabular}

\section{DIATOMS}

$\begin{array}{lrrrr}\text { Cyclotella gamma } & 494.4 \pm 21.6 \mathrm{~b} & 282.9 \pm 9.7 \mathrm{a} & 149.0 \pm 7.5 \mathrm{~b} & 241.8 \pm 21.7 \mathrm{a} \\ \begin{array}{l}\text { Cyclotella } \\ \text { meneghiniana }\end{array} & 959.4 \pm 56.8 \mathrm{a} & 224.6 \pm 7.6 \mathrm{~b} & 265.6 \pm 9.7 \mathrm{a} & 255.4 \pm 11.3 \mathrm{a} \\ \begin{array}{l}\text { Synedra acus } \\ \text { Synedra radians }\end{array} & 259.3 \pm 11.5 \mathrm{~d} & 167.3 \pm 4.6 \mathrm{~b} & 159.4 \pm 8.1 \mathrm{~b} & 168.7 \pm 5.6 \mathrm{~b} \\ & 336.9 \pm 7.8 \mathrm{c} & 49.4 \pm 2.5 \mathrm{c} & 60.5 \pm 6.7 \mathrm{c} & 92.0 \pm 4.7 \mathrm{~d}\end{array}$

\section{GREEN ALGAE}

\begin{tabular}{lrrrr} 
Chlamydomonas sp. & $46.5 \pm 3.0 \mathrm{f}$ & $33.1 \pm 1.6 \mathrm{f}$ & $58.1 \pm 1.8 \mathrm{c}$ & $116.5 \pm 9.8 \mathrm{c}$ \\
Chlorella sp. & $72.9 \pm 4.6 \mathrm{f}$ & $52.6 \pm 2.4 \mathrm{e}$ & $52.2 \pm 1.4 \mathrm{c}$ & $67.8 \pm 1.8 \mathrm{e}$ \\
Pediastrum sp. & $536.6 \pm 24.4 \mathrm{~b}$ & $88.8 \pm 6.3 \mathrm{~d}$ & $28.0 \pm 3.0 \mathrm{~d}$ & $42.4 \pm 2.2 \mathrm{f}$ \\
$\begin{array}{l}\text { Scenedesmus } \\
\text { quadricauda }\end{array}$ & $171.0 \pm 8.9 \mathrm{e}$ & $80.7 \pm 2.9 \mathrm{~d}$ & $54.9 \pm 1.7 \mathrm{c}$ & $28.8 \pm 1.2 \mathrm{f}$ \\
\hline
\end{tabular}

${ }^{1}$ Mean \pm SEM of three separate determinations. Differences among treatment means determined by analysis of variance $(P<0.05)$. Means followed by the same letter within columns are not significantly different $(P>0.05$; Duncan's multiple range test). 
showed stimulatory effects on chlorophyll $a$ content of a green alga Scenedesmus sp. at low concentrations ( 10 and $20 \mu \mathrm{g} / \mathrm{L}$ ) after a 7-day exposure. Stimulatory effects were also detected when a culture of Scenedesmus sp. was exposed to the phenylurea herbicide, patoran (El-Dib et al. 1991). The stimulation of growth observed at low concentrations of toxicants may be the result of adaptation of the photosynthetic pigments (Hatfield et al. 1989, Gustavson and Wangberg 1995, Koenig 1990) that allows for increased growth at lower concentrations and longer exposure periods.

Some plants, such as maize or millet, possess efficient detoxification mechanisms to detoxify atrazine (Ebert and Dumford 1976). As a consequence, atrazine can be used as a selective herbicide in production agriculture. It is apparent from this study that different species and perhaps divisions of freshwater algae exhibit different responses to atrazine exposure. Therefore, selective toxicity of pesticides or other organic contaminants of aquatic systems could alter species composition, decrease diversity, interfere with normal successional patterns, and alter food webs as a whole. The phenomenon of differential algal sensitivity to contaminant stress described by Wurster (1968) asserts that certain species or groups within phytoplankton communities possess the inherent ability to resist pollutant stress far better than do others. The results of the present experiment suggest the need for further research into the interaction of atrazine and freshwater algae to better understand the ecotoxicity of atrazine to a broader range of taxa. An understanding of the factors responsible for differential toxicity in algae will improve our ability to predict the impact of aquatic contaminants on freshwater ecosystems.

Acknowledgments. This work was supported by the USGS Section 104 Program. The authors thank Ray Lewis and Susan Jensen for technical advice and Stephen Katchman for statistical consultation. Drs. Kenneth Pruess and Susan Jensen provided critical reviews. Published with approval of the Director as Journal Series paper 11725, Nebraska Agricultural Research Division and contribution no. 938 of the Department of Entomology, University of Nebraska-Lincoln.

\section{REFERENCES}

Abou-Waly H, Abou-Setta MM, Nigg HN, Mallory LL (1991) Growth response of freshwater algae, Anabaena flos-aquae and Selenastrum capricornutum to atrazine and hexazinone herbicides. Bull Environ Contam Toxicol 46: 223-229

Anton FA, Laborda E, Laborda P (1993) Acute toxicity of technical captan to algae and fish. Bull Environ Contamin Toxicol 50: 392-399

Blaise CR (1993) Practical laboratory applications with micro-algae for hazard assessment of aquatic contaminants. pp. 83-108. In Richardson M, ed., Ecotoxicology Monitoring. VCH, New York

Boutin C, Freemark KE, Keddy CJ (1993) Proposed guideline for registration of chemical pesticides: Nontarget plant testing and evaluation. Technical Report Series 145. Environment Canada, Ottawa, Ontario

Ebert E, Dumford SW (1976) Effects of triazine herbicides on the physiology of plants. Residue Rev 65: 2-103

El-Dib MA, Shehata SA, Abou-Waly HF (1989) Response of freshwater alga Scenedesmus to triazine herbicide. Water Air Soil Pollut 48: 307-316

El-Dib MA, Ahehata SA, Abou-Waly HF (1991) Response of freshwater algae (Scenedesmus spp.) to phenylurea herbicides. Water Air Soil Pollut 55: 295-303 
Guillard RRL (1975) Culture of phytoplankton for feeding marine invertebrates. In Smith WL, Chanley MH (eds) Culture of marine invertebrate animals. pp. 2960 Plenum Publishing Corp, New York

Gustavson K, Wängberg S-Å (1995) Tolerance induction and succession in microalgae communities exposed to copper and atrazine. Aquat Toxicol 32: 283-302

Hatfield PM, Guikema JA, St. John JB, Gendel SM (1989) Characterization of the adaptation response of Anacystis nidulans to growth in the presence of sublethal doses of herbicide. Curr Microbiol 18: 369-374.

Herman D, Kaushik NK, Solomon KR (1986) Impact of atrazine on periphyton in freshwater enclosures and some ecological consequences. Can J Fish Aquat Sci 43: 1917-1925

Hersh CM, Crumpton WG (1987) Determination of growth rate depression of some green algae by atrazine. Bull Environ Contam Toxicol 39: 1041-1048

Hersh CM, Crumpton WF (1989) Atrazine tolerance of algae isolated from two agricultural streams. Environ Toxicol Chem 8: 327-332

Huber W (1993) Ecotoxicological relevance of atrazine in aquatic systems. Environ Toxicol Chem 12: $1865-1881$

Johnson TB (1986) Potential impact of selected agricultural chemical contaminants on a northern prairie wetland: a microcosm evaluation. Environ Toxicol Chem 12: 1865-1881

Kasai F, Takamura N, Hatakeyama S (1993) Effects of smetryne on growth of various freshwater algal taxa. Environ Pollut 79: 77-83

Kent RA, Currie D (1995) Predicting algal sensitivity to a pesticide stress. Environ Toxicol Chem 14: 983-991

Kirby MF, Sheahan DA (1994) Effects of atrazine, isoproturn and mecoprop on the macrophyte Lemna minor and alga Scenedemus subspicatus. Bull Environ Contam Toxicol 53: 120-126

Kirkwood RC, Fletcher WW (1970) Factors influencing the herbicidal efficiency of MCPA and MCPB in three species of micro-algae. Weed Res 10: 3-10

Koenig F (1990) Shade adaptation in cyanobacteria. Photosynthesis Res. 26: 29-37

Larsen DP, DeNoyelles F Jr, Stay F, Shiroyama T (1986) Comparisons of single species, microcosm and experimental pond responses to atrazine exposure. Environ Toxicol Chem 5: 179-190

Megharaj M, Venkateswarlu K, Rao AS (1987) Influence of cypermethrin and fenvalerate on a green alga and three cyanobacteria isolated from soil. Ecotoxicol Environ Saf 14: 142-146

Nichols HW (1973) Growth media - freshwater. In Stein JR (ed), Handbook of Phycological methods: Culture Methods and Growth Measurements. pp. 7-24, Cambridge University Press, New York

Okay OS, Morkoc E (1994) Effects of two herbicidal wastewaters on Chlorella sp. and Phaeodactylum tricornutum. Environ Pollut 84: 1-6

SAS Institute (1994) SAS Users Guide, Vol 2. SAS Institute, Cary, NC

Shehata SA, El-Dib MA, Abou-Waly HF (1993) Effect of Triazine compounds on freshwater algae. Bull Environ Contam Toxicol 50: 369-376

Solomon KR, Baker DB, Richards RP, Dixon KR, Klaine SJ, La Point TW, Kendall RJ, Weisskopf CP, Giddings JM, Giesy JP, Hall LW Jr, Williams WM (1996) Ecological risk assessment of atrazine in North America surface waters. Environ Toxicol Chem 15: 31-76

U.S. Environmental Protection Agency (1989) Short-term methods for estimating the chronic toxicity of effluents and receiving waters to freshwater organisms. 2nd ed. EPA 1.23/5:600/4-89/001

Walsh GE, Deans CH, McLaughlin LL (1987) Comparison of the $\mathrm{EC}_{50} \mathrm{~s}$ of algal toxicity tests calculated by methods. Environ Toxicol Chem 6: 767-770

Welschmeyer NA (1994) Fluorometric analysis of chlorophyll $a$ in the presence of chlorophyll $b$ and pheopigments. Limn Oceanogr 39:1985-1992

Wurster CF (1968) DDT reduced photosynthesis by marine phytoplankton. Science 159: 339-351 